\title{
Westward the Course of Empire Takes Its Way Through Tea
}

\section{Leslie Holmes, University of Alberta}

\begin{abstract}
The government of the Dominion of Canada hoped their western territory would be filled with immigrants eager to work the land and further strengthen the British Empire in the early $20^{\text {th }}$ century. British stock were viewed as ideal settlers as they would be able to represent and maintain the customs and behavior of the British Empire. Many brought with them to the Canadian frontier a variety of traditions - one of which was the habit of drinking tea. How did tea reinforce British identity and Empire in the Canadian West in the late $19^{\text {th }}$ and early $20^{\text {th }}$ centuries? This paper contends that tea was a powerful tool for nation builders because it reinforced British identity and empire.
\end{abstract}

\section{Introduction}

By 1879, the Conservative Government of the Dominion of Canada had implemented the National Policy, through which they hoped their western territory would be populated with immigrants eager to work the land and further strengthen the British Empire. While immigrants from a variety of backgrounds were encouraged to settle the land, many viewed immigrants from Britain as ideal. This was because they would be able to represent the Empire as well as maintain its customs and ways of behavior. Many of these British immigrants brought with them to

\author{
Past Imperfect \\ 16 (2010) | ( ) | ISSN 1711-053X | elSSN 1718-4487
}


the Canadian frontier a variety of traditions - one of which was the habit of drinking tea.

My paper argues that tea reinforced British identity and Empire in the Canadian West in the late $19^{\text {th }}$ and early $20^{\text {th }}$ century. Tea was a powerful tool for nation building. Through an analysis of various primary sources which include photographs, diaries, newspaper advertisements, articles, as well as numerous secondary sources concerning tea consumption, I will explore the ways in which the consumption of tea shaped Canadian identity and reinforced the relationship between Canadians and the Empire.

The first section of this paper discusses the ways tea was consumed in Eastern Canada in the $19^{\text {th }}$ century. It draws from prominent settlers like Susanna Moodie. The second section will consider the nation-building goals of the Dominion of Canada and the ways by which mass immigration compromised and reinforced imperialism and Britishness at on and the same time. The third and final section looks at the way tea was consumed as well as promoted and advertized on the Canadian Prairies, with a focus on the city of Edmonton.

\section{Tea in Eastern Canada}

Before discussing the Canadian West, it is important to consider the way in which tea was consumed in Eastern Canada. The significance of tea in Eastern Canada has been demonstrated in historian Kathryn Carter's discussion of the account book diary of Emma Chadwick, which survives from 1859-1860. Born in Britain in 1820, she moved with her husband to Prince 
Edward Island in 1859. It is clear that they wished to maintain their British values and lifestyle as her husband Critchlow brought numerous items with them, including a spinet piano, gothic chair, large dining table and a mahogany chest, in "anticipating his future career as a gentleman farmer in the New World." ${ }^{1}$ What is significant about this example was the way in which Emma helped to manage the family income-through a barter economy heavily reliant on the tea trade. Examples of this system can be found in her method of labelling accounts include: "tea given on trust" and "Mrs. D. McEachern tea a/c."2 This notation demonstrates the economic and material value of tea in the area at the time; it enabled this couple to succeed in the Maritimes but also maintain their British traditions of drinking tea, both public and private, at the same time.

Carter's discussion and analysis of tea in Prince Edward Island helps us to understand how tea as a commodity and a ritual maintained its significance as it crossed the Atlantic Ocean. For Chadwick, as well as others in a similar situation, tea was both important for social interactions and material transactions. Carter explains that "tea is currency in a barter economy, but it is also an integral part of her [Chadwick's] social life, for other entries show that taking tea with neighbors is one of Emma's more frequent social events." ${ }^{3}$ The way in which tea was consumed in this time and place demonstrates that it was held in high esteem as it maintained British traditions and customs.

\footnotetext{
${ }^{1}$ Kathryn Carter, "An Economy of Words: Emma Chadwick Stretch's Account Book Diary, 1859-1860," Acadiensis, XXIX, 1 (Autumn, 1999), 45.

${ }^{2}$ Ibid., 46.

${ }^{3}$ Ibid., 48. 
Chadwick reveals tea as a kind of currency when there was no tea. Carter explains that Emma relied heavily on tea shipments from her brother-in-law, Tom Stretch. The two of them communicated by letters, and there was a brief interruption of correspondence. Emma "alludes to her expectation of a reply or a shipment of tea from" Tom. This situation meant waiting for news of tea but also potentially accepting the reality of no tea. ${ }^{4}$ The lack of tea had not only ramifications on people's livelihood and success, but also social implications, as the act of taking tea was ended as a result. For settlers, being reliant on tea shipments from friends and family from Britain is in contrast to those in the Canadian West only twenty years later, who had access to the Eaton's Catalogue as well as numerous shops and stores. This difference could have possibly had an effect on British identity, for in Chadwick's circumstances, ties to Britain also equated to success, on both an economic and social level.

More than Maritimers, many Ontario families sent a large number of settlers to the prairies beginning in the 1880s, which is one reason it is important to see how tea consumption moved across the nation. ${ }^{5}$ One example of this transfer of traditions is in the written account Roughing it in the Bush or Life in Canada by Susanna Moodie. In 1832, she and her husband migrated to Upper Canada and her writings regularly mention tea. The way in which she discussed it demonstrates the way she viewed tea as essential to everyday life. Because of the cost, the couple was unable to afford tea and sugar and as a result she wrote, "I

\footnotetext{
${ }^{4}$ Ibid.

${ }^{5}$ Howard Palmer, Alberta: a New History (Edmonton: Hurtig Publishers Ltd., 1990), 65.

Past Imperfect

16 (2010) | @ | ISSN 1711-053X | elSSN 1718-4487
} 
missed tea very much; we rang the changes upon peppermint and sage, taking the one herb at our breakfast, the other at our tea, until I found an excellent substitute for both in the root of the dandelion." 6 This development of domestic tea recipes demonstrates just how essential tea was to settlers like Moodie, who even without their normal tea, adapted to make sure they still had something similar. The way that Moodie mentioned tea in some instances suggests how much of a comfort tea brought to her. She writes, "As we left her cottage, and jogged on, Emilia whispered laughing, 'I hope you are satisfied with your good dinner? Was not the pea-soup excellent? - and that cup of nice hot tea!-I never relished anything more in my life."'7 The manner this woman consumed tea also hints at her British identity, as she drank tea with sugar. ${ }^{8}$ This was the most common way the British drank tea and historian Woodruff D. Smith explains that in Britain, more so than anywhere else, drinking tea in the $18^{\text {th }}$ and $19^{\text {th }}$ centuries was focused around meals. This was a type of domestic ritual where tea and sugar were served along with certain foods. ${ }^{9}$ Moodie also consistently had afternoon tea prepared for herself, her husband, and their guests at times. At this time they regularly had "a cup of tea and a slice of bread"10 The example of Susanna Moodie, who lived in relative isolation compared to her home in Britain, allows us to understand how tea maintained its importance for settlers even in the isolated circumstances in the "bush" of Canada and in

\footnotetext{
${ }^{6}$ Susanna Moodie, Roughing it in the Bush, or, Life in Canada, (Toronto: Hunter Rose, 1871), 377.

${ }^{7}$ Ibid., 498.

${ }^{8}$ Ibid., 490.

${ }^{9}$ Woodruff D. Smith, "Complications of the Commonplace: Tea, Sugar, and Imperialism," Journal of Interdisciplinary History 23, 2 (Autumn, 1992), 275.

${ }^{10}$ Moodie, Roughing it, 267.

Past Imperfect

16 (2010) | @ | ISSN 1711-053X | elSSN 1718-4487
} 
particular, to those who settled the West.

\section{The Impact of Mass Immigration and Settlement}

In order to understand the nation and the nation building goals of the Canadian government, it is important to explain the way in which the government approached immigration and settlement of the prairies. This, in turn, helps us to comprehend the setting and climate in which tea was consumed. Historian Sheila McManus explains that Canadian officials saw the potential way the West could influence the country's destiny and were enthusiastic about what the West's role was in shaping the Dominion within the British Empire. The expansion and settlement of the Canadian Prairies would not only increase the size of the empire but would also benefit it due to its agricultural, mineral and commercial resources. These resources would supply the mother country and as settlers "added to Canada's population and wealth, that prosperity could be directed back to England, thus benefiting everyone." 11 It is important to note that the English were considered the ideal immigrant group and Canadian immigration agents promoted the Prairie Provinces as an extension of Britain, under one flag and one common goal. Attempts were made to boost the prairie image as similar "to home" in many ways and to create a Canada that was only a twenty day trip from England.12 After 1896 in particular, there were immigrants from all over Europe and the United States also

\footnotetext{
${ }^{11}$ Sheila McManus, The Line Which Separates: Race, Gender, and the Making of the Alberta-Montana Borderlands (Edmonton: University of Alberta Press, 2005), 117.

${ }^{12}$ McManus, The Line Which Separates, 123. 
moving onto the prairies. ${ }^{13}$ On the one hand, these ethnic immigrants were helping the Empire grow and succeed but at the same time they were compromising its Britishness.

As a result of mass immigration in the late $19^{\text {th }}$ and early $20^{\text {th }}$ centuries to the Canadian Prairies, the need for settlers of British origin to maintain their traditions, such as drinking tea, was seen as essential for maintaining British dominance and for the preservation of the Empire. In the 1880s and 1890s, British immigrants and Ontarians made up the majority of settlers to the Prairies. This gave them a strong base for when settlers from all over Europe and the United States moved into the area. ${ }^{14}$ By the turn of the century, the British made up the largest group in the Canadian West and though ideal settlers in the eyes of the Dominion Government, they were often weak and unsuccessful in farming. As a result, many settled in the urban centres and entered careers such as business, medicine, law and politics. This development was significant, because although they were unsuccessful at fulfilling their role as farmers, many settlers of British origin (especially those from Ontario) had superior knowledge of the English language and Canadian institutions. Their increased educational background allowed them to thrive in positions of power such as teaching, politics and legal work. ${ }^{15}$ They were the elites of the Prairie Provinces while other immigrant groups such as Germans, Ukrainians and Scandinavians settled in and around the urban spaces and fulfilled their role as farmers. ${ }^{16}$ The need for British settlers to

\footnotetext{
${ }^{13}$ Palmer, Alberta, 68.

14 Ibid., 74.

${ }^{15}$ Ibid., 65.

${ }^{16}$ Ibid., 80-81.
} 
maintain and assert their Britishness was paramount as their identity and Empire; qualities they thought were being potentially compromised by large numbers of non-British immigrants. With loyalty to God, King and Country (and tea), many Anglo-Saxons imbued with their Social Darwinist thought, developed hostility to immigrants of non-British origin. An emphasis was placed "on preserving the cultural aspects of British traditions," such as tea, in order to maintain the British Empire and proclaim its power over all within it.17

The influence of tea and thus the preservation of things British on the prairies can be seen in organizations such as the Imperial Order of the Daughters of the Empire (IODE) who were "white settlers' attempting to create a British Canada."18 This was a patriotic organization with the motto "one flag, one throne, one Empire." 19 These women demonstrated the kind of mentality many of these British settlers lived within. Their policy concerning immigrants highlights how important British tradition was in order to maintain their ideal empire. In the eyes of the IODE it was their mission and goal to create a Canada that mimicked Britain and it was through British immigrants who would populate the Dominion that they would be successful. The IODE believed in "a framework of powerful racial preferences [that] was constructed as the norm to which all others must assimilate."20 Historian Katie Pickles explains that the construction of Britishness in Canada was unique as the identity of "The English," or "the Anglo-Canadian." It has often been a

\footnotetext{
${ }^{17}$ Ibid., 78.

${ }^{18}$ Katie Pickles, Female Imperialism and National Identity: Imperial Order of the Daughters of the Empire (Manchester: Manchester University Press, 2002), 15.

${ }^{19}$ Ibid.,16.

${ }^{20}$ Ibid., 36.
} 
combination of many groups including the British, Welsh, Scottish and Irish in order to create a larger and more powerful single group. ${ }^{21}$ This confusion and combination of groups was a way in which to disempower other ethnic groups around them. ${ }^{22}$ This mindset is the climate that reinforced Britishness and allows us to understand why a ritual like tea drinking would be so important for a group like the IODE.

Outside of the time period of this study, yet nonetheless important to consider is one particular connection between the IODE and tea. The IODE held fundraising activities and promotional events that served tea. Collaboration between the IODE and the Society of the Overseas Settlement of British Women (SOSBW) in a 1928 cross-Canada tour demonstrates how tea was used as a powerful symbol of the Empire. Throughout the tour, tea was offered in various cities, including Calgary. This tour was meant to "transmit back to Britain an appropriate image of Canada" and it conducted "a narrative of superior British-based culture, economy and politics." 23 The use of tea-based events helped to maintain this connection between the two countries and further reinforced the power of the Empire in the eyes of these young girls and women.

Tea was consumed on the prairies within the context of reinforcing British identity, what Carl Berger calls "Canadian nationalism." Under this "Greater Britain" framework that future Prime Minister R.B. Bennett stated in 1914, "An independent Canada means that we Canadians are afraid of the responsibility and obligation of power, afraid to accept the responsibilities of

\footnotetext{
${ }^{21}$ Ibid.

${ }^{22}$ Ibid., 37-38.

${ }^{23}$ Ibid., 75-78.
} 
our race and breed; Afraid to think we are Britons."24 Clearly an imperialist, Bennett spoke the words that many of his fellow Canadians felt. In his eyes, as well as many others, there was no difference between being Canadian and British. With this idea in mind, one of the best ways to analyze tea consumption on the Prairies is by looking at similarities between Britain and Canada.

\section{Taking Tea on the Prairies}

A common custom in both places was in the way women "took tea." The focus in both Britain and Eastern Canada in the $19^{\text {th }}$ century was class distinction. On the prairies the issue of social and ethnic hierarchies and boundaries played a role as well. "At homes" and other tea related events were regularly advertised in the Edmonton Bulletin Socials section. Common in Victorian England, at homes were a designated day and time once a week or month in which a prominent woman would be at home to accept callers. ${ }^{25}$ On March 18, 1907, the Bulletin reported that "Mrs. J.J. Tull will receive on the second and third Thursdays of each month at her residence, 520 Fraser Avenue."26 These types of notifications were common in the newspaper each week. It was also important to be fashionable at these events and this is highlighted in the newspaper as well. For example, on January 17, 1907, "Mrs. Short's tea yesterday was one of the largest and most enjoyable teas of the season...Mrs.

\footnotetext{
${ }^{24}$ Philip Resnick, The European Roots of Canadian Identity (Toronto: Broadview Press Ltd., 2005), 25.

${ }^{25}$ Andrea Broomfield, Food and Cooking in Victorian England: A History

(Westport, Connecticut: Praeger Publishers, 2007), 66.

${ }^{26}$ The Edmonton Bulletin, March 18, 1907, Page 2. 
Short received her guests alone, wearing an elaborate gown of mauve silk crepe de chipe trimmed with medallions of cream lace and mauve embroidery." 27 A similar announcement was written about Mrs. J. Macleod who was "gowned in a soft grey silk dress with cream lace vest" at her at home on January 23, 1908. ${ }^{28}$ Historian Andrea Broomfield explains that "tea gowns were designed to allow women relaxed freedom of movement" and created a flowing and soft look as a woman moved about the room. ${ }^{29}$ It is clear by the social announcements in the newspaper that these at homes were a significant social event, one that was observed and scrutinized by those involved.

These "at homes" were a common middle to upper class ritual; however, in western Canada they were also distinctly British in a place where immigrants from all over Europe were settling. This made the practice of at homes a method to reinforce not only British traditions but also maintain the British at the top of the social and ethnic hierarchy on the prairies. Analyzing the Socials section in the Edmonton Bulletin, it is clear that there was a particular agenda and focus; these events were strictly for British women of middle to upper classes. If we consider the names of the women attending these events, it is evident that in order to attend, you had to be of British origin in some respect. Women such as Mrs. Rutherford (the first Premier of Alberta's wife), Mrs. Jellet, Mrs. J.J. Tull, Mrs. Bishop, Miss. Taylor and Mrs. Cuthbert are only a few of the many women who held and attended these parties. Within the confines of the newspaper Socials analyzed, there were no names of a distinct

${ }^{27}$ Ibid., January 17, 1907, Page 2.

${ }^{28}$ Ibid., January 23, 1908, Page 8.

${ }^{29}$ Broomfield, Food and Cooking, 73.

Past Imperfect

16 (2010) | @ | ISSN 1711-053X | elSSN 1718-4487 
ethnicity, such as German or Scandinavian, present. It is clear that these tea events shaped and reinforced not only middle class boundaries, but also those of ethnicity. The tradition of drinking tea in an at home context for example, "draw[s] us into the elaborate world of ritual and the sometimes ruthless processes of inclusion and exclusion by which membership" in both the middle class and British society was determined. ${ }^{30}$

The rituals surrounding events such as "at homes" are important to consider. Within the descriptions of "at homes" in the Socials, there is often mention of the women who assisted and aided the hostess in hosting their party. For example, on July 3, 1907 "Miss Morice, who leaves Calgary this week for Edmonton, entertained there at a delightful tea last Saturday afternoon at the tea rooms, which were charmingly arranged with sweet peas and Alabama smilax. Miss Macleod assisted Miss Morice." 31 Assisting with an "at home" and being chosen to help pour tea is significant as it demonstrates that there was a hierarchy amongst those attending the event. If a woman was chosen to assist and pour tea, the hostess as well as by those in attendance held her in high esteem. While rituals and traditions surrounding tea are complicated, the way women interacted with each other while taking tea reinforced social hierarchies and relationships. ${ }^{32}$ Often events were also "in honor" of a particular woman. For example, the Socials section of the December 3, 1910 edition of the Edmonton Bulletin wrote that "Mrs. Forin entertained very delightfully at the tea hour, in honor of Mrs. Hunt of England," while "Mrs. T.W Lines entertained a

\footnotetext{
${ }^{30}$ Poole, “Taking Tea," 15.

${ }^{31}$ The Edmonton Bulletin, July 3, 1907, Page 3.

32 Broomfield, Food and Cooking, 70-74.
} 
smart little tea in honor of her sister Mrs. (Dr.) Borroughs of Kamloops." 33 These tea events were a way for women to demonstrate their own importance as well as a way to promote other women within their social sphere.

Taking tea was a way for settlers to become acquainted with each other and develop and maintain a shared social identity. This could be done through formalized at homes, as previously discussed. However, Broomfield demonstrates that taking tea could also have been a more informal event. Taking tea with family and friends was "a time where community goodwill and friendship" and "outweighed whatever rules and decorum appeared in etiquette guides." For women in more rural areas, they could not and did not always go out calling at teatime or expect callers. Instead, they took a tea break alone or with family members within their own household. ${ }^{34}$ Either way, these British prairie settlers, just like their Eastern Canadian predecessors had done before them, mirrored their counterparts in Britain. While settlers in the Maritimes and Central Canada in the early part of the $19^{\text {th }}$ century may have used tea as a way to distinguish class, since "the tea ritual, as a class experience, had its British roots in the social evolution of the middle ranks in the mid 17th century," for British settlers on the prairies there was an added emphasis on ethnic and racial boundaries as well. ${ }^{35}$ Historian Ann Judith Poole further explains that "gentility was a transnational condition" and even in the Canadian West, this idea

33 The Edmonton Bulletin, December 3, 1910, Page 9.

${ }^{34}$ Broomfield, Food and Cooking, 73-74.

${ }^{35}$ Ann Judith Poole, "Taking Tea in the Parlour: Middle Class Formation and Gender Construction in Nova Scotia and New Brunswick, 1760- 1850" (MA Thesis: Simon Fraser University, 2007),.6. 
was maintained. ${ }^{36}$ Palmer also observes that specific British gentlewomen were sought after to ensure the future of the British Empire. This benefited the British Empire in two ways. First there was a surplus of females in England, with less of their male counterparts left in Britain due to immigration and military service. This meant that the Canadian West could benefit from an increased white and British female presence. Secondly, "the British Women's Emigration Association encourage emigration to Canada, picturing Canada as a 'cultural backwoods, desperately in need of the refining touch of British gentlewomen.'”37 British women's presence on the prairies would not only help remedy issues of sex ratio disparity between white British settlers, it would also help in the maintenance and reinforcement of the British Empire, as these women often partook in tea drinking events.

When we look at photographs from this time period, it is clear that there was also an element of informal tea drinking within the household occurring on the prairies. Unlike the social events of "at homes" and afternoon teas published in the newspaper, many of the photos available demonstrate that tea consumption needed to fit into the lifestyle that came along with living on the Canadian Prairies. Many of the photos portray people drinking tea outside, setting up their tea accoutrements on a small table and drinking from a porcelain or earthenware tea cup. One example of this can be seen in the photograph titled "Tea break for camp cook and visitors, Midnapore area, Alberta" where two women and a young girl are seen drinking tea outside

\footnotetext{
${ }^{36}$ Poole, "Taking Tea," 26.

${ }^{37}$ Palmer, Alberta, 81. 
of a wagon. ${ }^{38}$ However, once established, settlers drank tea just as they would have in Britain. This can be seen in the photographs "Deane family and friends, Maple Creek, Saskatchewan" taken in 1906 in comparison to a photo of a Victorian Afternoon Tea in Britain. ${ }^{39}$ Both photographs have women and men drinking tea outside in what seems to be a fairly familiar setting. Also, unlike the "at homes", these photos are of smaller groups and within the confines of family tea. As previously discussed, these photos demonstrate the more informal teatime that British subjects participated in. There were obviously rituals and rules that were followed, but it involved close family and friends in a more private setting. This can also been seen in the photo "Slave Lake tea party" from 1922, with the Levason and White families. ${ }^{40}$ It is also important to note that without background information on the photos, there is little to no photographic hints that any of the photos were taken in Canada as their dress and actions create the possible reality that they were in Britain.

The act of drinking tea was a way to connect with Britain and extend the power of the Empire into their homes. These photos demonstrate what Smith explains to be a "domestic ritual" and one that reaffirmed fashion and status, even on the Canadian Plains. Smith states that tea's "connected status with a willingness to engage in a ritualistic, and not inexpensive, form of

\footnotetext{
${ }^{38}$ Glenbow Archives and Museum: no. NA-3959-31, Tea Break for camp cook and visitors, Midnapore area, Alberta (ca. 1913).

${ }^{39}$ Glenbow Archives and Museum: no. NA-3668-10, Deane Family and Friends, Maple Creek, Saskatchewan (Ca. 1906).

Hulton Archive: no. HH9794-001, Afternoon Tea. http://www.gettyimages.com/detail/HH9794-001/Hulton-Archive.

${ }^{40}$ Provincial Archives of Alberta: no. A14848, Slave Lake Tea Party (ca. 1922). 
consumption displaying moral standing." ${ }^{41}$ For settlers, this also presented their standing as British (which was inherently respectable) and of higher social and ethnic rank within the hierarchy. It is the act of drinking tea, in both public and private that created and supported their higher status and increased respectability.

When considering tea consumption on the prairies, the Eaton's Catalogue is another useful resource. In the 1890s the company offered a wide variety of teas to choose from. In an effort to convince their customers of their superior product, they wrote:

In this department we excel, being thoroughly familiar with the peculiar qualities possessed by the different varieties of Indian, Ceylon and China teas, we can produce results unattainable by amateurs or inexperienced dealers. ${ }^{42}$

No doubt, the need for superior tea was important for Eaton's, as they promised their product to be of highest quality. As will be discussed in depth further below, the tea industry was a competitive market, and Eaton's was a part of that. Not only did the company sell tea, it also offered a variety of tea sets, up to forty-four pieces in size. Teapots such as the "special line brown decorated teapot" or the "very pretty decorated teapot" were also sold. ${ }^{43}$ The wide variety of tea goods available demonstrates

${ }^{41}$ Smith, Tea, Sugar, and Imperialism, 277.

${ }^{42}$ John Eaton Catalogue No. 2, 189-?, Page 102. Library and Archives of Canada < http://www.collectionscanada.gc.ca/mailorder/029006-119.01e.php?\&page_ecopy=nlc003941.102\&\&\&\&\&\&PHPSESSID=vchlpbfipmuookjm8j vjmfafl3> (December 14, 2009.)

${ }^{43}$ John Eaton Catalogue No. 2, 189-?, Page 155. Library and Archives of Canada < http://www.collectionscanada.gc.ca/mailorder/029006-119.01-

Past Imperfect

16 (2010) | @ | ISSN 1711-053X | elSSN 1718-4487 
just how important taking tea was and goes hand in hand with the number of teas offered. This also shows just how high in demand tea was in the West at this time. Poole explains that objects, such as porcelain tea ware, as well as parlour furniture, helped to create settlers' social identity and allowed them to distinguish themselves from others, be it lower classes or other ethnicities. ${ }^{44}$ Drinking from a proper tea cup and drinking "English" tea meant membership into a specific group and enabled the creation of social and racial boundaries in the Canadian West. 45 It is important to note that since the Eaton's Catalogue was published and sold in Canada in only the English language, it most likely meant that it targeted a specific group of people-English settlers. The catalogue was not regularly published in the second most spoken language in Canada, French, until 1927 and the company preferred that orders be written in English. ${ }^{46}$ Eaton's did not cater to major ethnic immigrant groups such as Germans or Ukrainians and the products and way in which they sold goods suggests a British dominant sales agenda.

The way tea was promoted and advertised explains how British values and traditions reigned supreme on the prairies. These adverts were full of British propaganda and imagery that promoted the empire and were mostly targeted at British settlers as a result. The wide variety of tea that was promoted and sold in this manner also reveals just how high a demand

e.php?\&page_ecopy=nlc003941.155\&\&PHPSESSID=vchlpbfipmuookjm8jvjmfaf 13> (December 14, 2009.)

${ }^{44}$ Poole, "Taking Tea," 16.

${ }^{45}$ Ibid., 22.

${ }^{46}$ Canadian Mail Order Catalogues: History, Library and Archives of Canada. <http://www.collectionscanada.gc.ca/mailorder/029006-200-e.html> (December 14, 2009.)

Past Imperfect

16 (2010) | ( ) | ISSN 1711-053X | eISSN 1718-4487 
there was for the product. An advertisement by Lipton's Tea, one of the largest tea suppliers in the world and of British origin, had some of the strongest symbols and images connected to the empire. Their advertisement in the March 26, 1898 issue of The Commercial states,

Lipton's Ceylon Teas-the finest in the world can produce. Pure, fragrant, delicious. Awarded highest honors at the World's Fair. Over one billion packages sold weekly. A trial will convince you of its merits. Mackenzie \& Mills- sole agents for Manitoba, the Territories and British Columbia. ${ }^{47}$

The tea tin in the advertisement has British images such as the British Crest in the centre. The tin also has printed on it: "Tea Merchant by special appointment to her Majesty Queen Victoria."48 Lipton's tea was one of the most popular teas available in Canada and the use of British imagery on their products and advertisements helped to reaffirm to settlers the association between tea and the empire.

Tea tins offer a symbolic and valuable insight into the pervasiveness of the empire on the Canadian Prairies. Just like the Lipton's image previously described, certain tins had patriotic images which reinforced the importance of being a British subject and the habit of drinking tea. There are two tea tins which stand out: the first was produced by Royal Shield Brand Tea in Winnipeg, Manitoba, which contained Ceylon and Indian tea. The outside panels are painted in blue and red and there is an image of a young man with a shield and some kind of

${ }^{47}$ The Commercial, Vol. 16, no. 29, March 26, 1898, Page 748.

${ }^{48}$ Ibid., 748.

Past Imperfect

16 (2010) | @ | ISSN 1711-053X | elSSN 1718-4487 
spear. ${ }^{49}$ This tea tin evokes feelings of patriotism and the strength of the British Empire. It may also have deeper symbolic meaning-as the tea itself represents the protection and maintenance of British identity and empire just as a shield would. This, along with Indian and Ceylon (Sri Lanka today) being part of the British Empire, clearly demonstrate how tea and its production go hand and hand with the empire's power and influence.

The second tea tin, from 1901, is by an unknown manufacturer, but it too has images of strength and patriotism that were no doubt used to promote tea drinking and the Empire. ${ }^{50}$ The images of Lord Kitchener and Lord Roberts are on two sides of the tin. These men were prominent and popular generals in the Boer War. This is significant, as the Boer War was an intensely symbolic one for Canada. The country was divided over the issue of Canada's involvement in an imperial war, but those of British origin felt a responsibility to fight for the empire because the empire was their empire. According to historian Carl Berger, not only was enlistment for the Boer War caused by a sense of duty to the British Empire, but there was also "the conviction that the Anglo-Saxon race held in its hand the destiny of the world, coupled with the belief that the race was enjoined by God to disseminate the seeds of civilization." 51 Enlistment for this war was voluntary in Canada, yet rates were quite high in British communities (for example the Alberta ranching community.) ${ }^{52}$ For many, this war was viewed as Canada's first

${ }^{49}$ Glenbow Archives and Museum: no. PI-15154, Tea Tin (No date).

${ }^{50}$ Glenbow Archives and Museum: no. C-9210, Patriotic Tea Tin (ca. 1901).

${ }^{51}$ Carl Berger, The Sense of Power: Studies in the Ideas of Canadian Imperialism, 1867-1914, (Toronto: University of Toronto Press, 1970), 251.

${ }^{52}$ Palmer, Alberta, 55. 
step onto the world stage and young Canadians fought well alongside the British. ${ }^{53}$ The Boer War symbolized both increased independence and responsibility for Canada as a young nation yet at the same time furthering attachment to the British Empire. This tea tin was a symbol of this war, and the images of the British generals on the side would remind tea drinkers of their patriotic responsibility to continue to support the empire, and to continue drinking tea. Smith explains that in Britain consuming tea and sugar was a patriotic act because it supported the empire. Wine, coffee and chocolate were products from Britain's political opponents and consuming them was to support the enemy. However, "the newly formed culture of respectability was the most important context within which the consumption of tea and sugar expanded in the eighteenth and nineteenth centuries"54 Drinking tea with sugar not only assisted the Empire, it also created respectability for the drinker. This respectability enforced the British hierarchy on the prairies.

The same patriotic ideas can be inferred from British china, which was sold in at least one Edmonton tea shop, Reed's Tea and Bazaar. The labels on the china crate stated: "Great Britain Delivers Royal Albert Crown China" with the Union Jack in the centre. Another label stated: "Britain Delivers the GoodsRoyal Doulton China."55 The store started to sell fine china and promoted its British origin by displaying the wooden cases with

\footnotetext{
${ }^{53}$ Canada: A People's History, The Boer War. <http://history.cbc.ca/history/?MIval=EpisContent.html\&series_id=1\&episode id=11\&chapter_id=2\&page_id=3\&lang=E> (December 14, 2009.)

${ }^{54}$ Smith, Tea, Sugar, and Imperialism, 277.

${ }^{55}$ Lan Chan-Marples, "Reed's Tea and Bazaar Store," Historical Research Report (Edmonton Parks and Recreation: Fort Edmonton Park, December 3, 1982), Figure 64 and 65.

Past Imperfect 16 (2010) | @ | ISSN 1711-053X | elSSN 1718-4487
} 
a Union Jack design mark on the outside of the crate. ${ }^{56}$ Just like the Eaton's Catalogue, these pieces of china were the very types of tea goods that settlers would have purchased and from which they would then consume tea out of. Each sip of tea was a taste of the British Empire. The British Maritime settlers had imported thousands of tons of English tea porcelain sets as a way to establish the colonial middle class and "increasingly the colonial middle class required specific tea equipment to signal membership." 57 The same can be said for Western settlers who reinforced their identity and Britishness through their purchases of tea cups, saucers, teaspoons and other tea ware in either Eaton's Catalogue or at one of the many tea shops in the urban centres. Every aspect of tea consumption, from the teacup to the tea itself and even the sugar mixed in, was a patriotic act.

The capital of Alberta, Edmonton, offers us an effective example of the impact of tea in through a close study of a successful tea store-- Reed's Tea Store and Bazaar. The Edmonton Bulletin on October 3, 1905 reported:

W.H. Reed, of Belleville, Ont. Is opening up a stock of tea, coffee, glass, chinaware, crockery and general bazaar stock in the Lee Block on Jasper Avenue... Mr. Reed has fifteen year's experience as manager of Stroud Bros., tea kings, who have stores all over Eastern Ontario. 58

Reed had worked under one of the most successful merchants in Eastern Canada, Daniel Stroud, who sold china, earthenware and

${ }^{56}$ Chan-Marples, "Reed's Tea," 33.

${ }^{57}$ Poole,"Taking Tea," 22.

${ }^{58}$ Chan-Marples, "Reed's Tea," 25.

Past Imperfect

16 (2010) | @ | ISSN 1711-053X | elSSN 1718-4487 
tea. ${ }^{59}$ After twenty-five years of working for Stroud, Reed moved to Edmonton in September of 1905. His business was a success and Reed decided to create a particular tea blend made specifically for Edmonton's water. Of course, Reed's Tea Store and Bazaar sold other brands of tea, and customers who regularly purchased tea included the Governor General. ${ }^{60}$ Tea was available in pre-packaged amounts or by weight. Reed's Bazaar was not the only the only store where tea was sold in Edmonton. There was The Edmonton Jobbing House, The Hudson's Bay Company, and Revillion Bros. Ltd., all of which had tea for sale. However, there were also specific tea companies, like New York \& Pacific Tea Company, the Edmonton Tea \& Coffee House and National Blend Tea House in competition with Reed's. ${ }^{61}$ The number of retailers available throughout Edmonton demonstrates just how popular the beverage was. This along with tea advertisements in the Edmonton Bulletin and the Canadian Magazine Advertiser for Ridgways Tea and Ram Lal's Pure Indian Tea reveal the strength of its promotion as well as the demand for tea. ${ }^{62}$

\section{Conclusion}

Through the analysis of tea consumption on the Canadian Prairies in the late $19^{\text {th }}$ and early $20^{\text {th }}$ century, it is clear that this beverage was a strong component in the creation and

\footnotetext{
${ }^{59}$ Ibid.

${ }^{60}$ Ibid., 28.

${ }^{61}$ Ibid., 34.

${ }^{62}$ The Edmonton Bulletin, June 3, 1908, Page 2. The Canadian Magazine Advertiser, 1898 Vol 12, no. 1. Page XXXVII.

Past Imperfect

16 (2010) | @ | ISSN 1711-053X | elSSN 1718-4487
} 
preservation of the British Empire. It reinforced social and ethnic boundaries that were present at the time through its strong British connections and connotations. The British immigrants that settled in the area helped to protect and strengthen the British Empire by drinking tea and maintaining particular traditions, such as at homes. They maintained a strong middle and upper class structure and upheld tea drinking as inherently British. This was done not only through social events but also through the manufacturing and promotion of tea as patriotic. The British Empire's expansion around world had a new frontier-the Canadian West-and with British settlers there to represent and preserve its agenda, in the eyes of many, it would no doubt succeed. What is interesting is that the fear of many about the "Americanization" of Canada would slowly become a legitimate one, due to Canada's increased independence as well as downfall of the British Empire. How tea traditions and consumption changed as well as the social and ethnic boundaries within it as a result is worth considering. 


\title{
Bibliography
}

Secondary Sources

Berger, Carl. The Sense of Power: Studies in the Ideas of Canadian Imperialism, 1867-1914. Toronto: University of Toronto Press, 1970.

Breen, David H. The Canadian Prairie West and the Ranching Frontier 1974-1924. Toronto: University of Toronto Press, 1983.

Broomfield, Andrea. Food and Cooking in Victorian England: A History. Westport, Connecticut: Praeger Publishers, 2007.

Carter, Kathryn. "Economy of Words: Chadwick Stretch's Account Book Diary, 1859-1860." Acadiensis XXIX, no. 1 (Autumn, 1999).

Chan-Marples, Lan. "Reed's Tea and Bazaar Store." Historical Research Report. Edmonton Parks and Recreation: Fort Edmonton Park, December 3, 1982.

McManus, Sheila. The Line Which Separates: Race, Gender, and the Making of the Alberta-Montana Borderlands. Edmonton: University of Alberta Press, 2005.

Owram, Doug. Promise of Eden: The Canadian Expansionist Movement and the Idea of the West, 1856-1900. Toronto: University of Toronto Press, 1980.

Palmer, Howard. Alberta: a New History. Edmonton: Hurtig Publishers Ltd., 1990.

Pickles, Katie. Female Imperialism and National Identity: Imperial Order of the Daughters of the Empire. Manchester: Manchester University Press, 2002.

\author{
Past Imperfect \\ 16 (2010) | ( ) | ISSN 1711-053X | elSSN 1718-4487
}


Poole, Ann Judith. "Taking Tea in the Parlour: Middle Class Formation and Gender Construction in Nova Scotia and New Brunswick, 1760- 1850.” MA Thesis: Simon Fraser University, 2007.

Resnick, Philip. The European Roots of Canadian Identity. Toronto: Broadview Press Ltd., 2005.

Smith, Woodruff D. "Complications of the Commonplace: Tea, Sugar, and Imperialism." Journal of Interdisciplinary History 23, no. 2 (Autumn, 1992).

Primary Sources

John Eaton Catalogue No. 2, 189-? Pages 102 and 155. Library and Archives of Canada

<http://www.collectionscanada.gc.ca/mailorder/029006100.01-e.php?PHPSESSID=vchlpbfipmuookjm8jvjmfafl3>

(December 14, 2009.)

Moodie, Susanna. Roughing it in the Bush, or, Life in Canada. Toronto: Hunter Rose, 1871.

The Canadian Magazine Advertiser: 1898, Vol 12, no. 1, Page XXXVII.

The Commercial: March 26, 1898, Vol 16, no. 29, Page 748.

The Edmonton Bulletin: December 3, 1910, Page 9. Our Future Our Past: Alberta Heritage Digitization Project Website. http://www.ourfutureourpast.ca/

The Edmonton Bulletin: January 17, 1907, Page 2. Our Future Our Past: Alberta Heritage Digitization Project Website. http://www.ourfutureourpast.ca/ 
The Edmonton Bulletin: January 23, 1908, Page 8. Our Future Our

Past: Alberta Heritage Digitization Project Website. http://www.ourfutureourpast.ca/

The Edmonton Bulletin: July 3, 1907, Page 3. Our Future Our Past: Alberta Heritage Digitization Project Website. http://www.ourfutureourpast.ca/

The Edmonton Bulletin: June 3, 1908, Page 2. Our Future Our Past: Alberta Heritage Digitization Project Website. http://www.ourfutureourpast.ca

The Edmonton Bulletin: March 18, 1907, Page 2. Our Future Our

Past: Alberta Heritage Digitization Project Website. http://www.ourfutureourpast.ca/ 